\title{
Forest Management Policy, Amenity Migration, and Community Well-Being in the American West: Reflections from the Northwest Forest Plan
}

\author{
Susan Charnley • Rebecca J. McLain • \\ Ellen M. Donoghue
}

Published online: 3 October 2008

(C) The Author(s) 2008. This article is published with open access at Springerlink.com

\begin{abstract}
This paper examines the relation between public land management policy, amenity migration, and socioeconomic well-being using the case of the Northwest Forest Plan - a forest management policy that caused 11.6 million acres of federal land in the US Pacific Northwest to be reallocated from commodity production to biodiversity services. Our analysis focuses on three propositions implicit in much of the amenity migration literature in the USA: land management policies that reduce commodity production and/or increase environmental protection (1) improve the natural amenity values of public lands; (2) increase amenity migration to communities near public lands; and (3) stimulate economic development and increase socioeconomic well-being in these communities. Our findings indicate that all three propositions are problematic and demonstrate the importance of community-scale analysis for understanding the relation between land management policies, amenity migration, and community well-being. We discuss the implications of our findings for public land management and rural community development.
\end{abstract}

Keywords Amenity migration - Forest management .

Rural development $\cdot$ Pacific Northwest

S. Charnley $(\bowtie) \cdot$ E. M. Donoghue

USDA Forest Service,

Pacific Northwest Research Station, 620 SW Main St., Suite 400, Portland, OR 97205, USA

e-mail: scharnley@fs.fed.us

E. M. Donoghue

e-mail: edonoghue@fs.fed.us

R. J. McLain

Institute for Culture and Ecology,

P.O. Box 6688, Portland, OR 97228, USA

e-mail: mclain@ifcae.org

\section{Introduction}

During the past 15 years federal forest management policy in the western USA has shifted from emphasizing sustained-yield timber production to focusing on biodiversity conservation and the protection of endangered species (Thomas et al. 2006). This shift has meant a major drop in the volume of timber harvested on federally-managed forest lands. Scholars interested in rural community development in the USA have debated whether this policy shift from commodity production to environmental protection has had positive or negative economic effects on communities near forests. The debate is shaped by changing understandings of the role of federal forests in regional economies, the relationship between federal timber production and community well-being, and commodity versus amenity-based models of economic development.

According to the commodity-based model of economic development, commercially-valuable commodities produced locally form an economic base for a community or region, and economic growth in these places is driven by external demand for the commodities. For example, logging, processing, and manufacturing produce wood and wood products for export, creating local employment opportunities, with positive economic effects in the community or region. These "base industries" also attract other firms that provide services to the base industries and their employees, further contributing to economic development. The wood products industry was an important economic sector in parts of the American west from the 1950s through the 1980s and was considered the economic base for many rural communities around federal forests. Wellbeing in these communities was believed to depend on the stability of the wood products industry, and on an even flow of timber from federal forest lands (Power 2006). The 
commodity-based model predicts that a shift from timber production to environmental protection on federal lands would have negative social and economic effects on workers in the wood products industry and on their communities. The notion of community stability has now been replaced by the concept of community resilience, recognizing that community well-being is affected by many variables (not just federal timber harvest levels), and that rural communities continually experience change and respond by taking advantage of new opportunities that arise (Donoghue and Sturtevant 2007).

The amenity-based model of economic development reflects more recent ideas about the relations between federal forests and community well-being. According to this model, rural communities having desirable physical and social environments attract tourists, new residents, and new businesses. New residents bring with them financial and human capital, and together with new businesses and tourists, create jobs (especially in the services sector), stimulating local economic development. Thus, "jobs follow people" (Goodstein 1999; Nelson 1999; Vias 1999). In-migration that occurs in a place because people are drawn to its natural and social features is termed "amenity migration". Public lands play an important role in amenity migration because of the natural amenities they provide. We define natural amenities as elements of the natural environment that people value and find attractive, making a location a more desirable place to live. Although natural amenities are subjective in nature, they typically include outdoor recreation opportunities, scenic beauty, open space, clean air and water, and environmental features such as water bodies, coastlines, mountains, and forests. The amenity-based model predicts that a change in federal forest management from commodity production to environmental protection would have positive social and economic effects in local communities because it would enhance the natural amenity values of forests, thereby increasing amenity migration to forest communities, with associated economic benefits.

This paper uses the case of the Northwest Forest Plan - a forest management policy implemented on 24 million acres of federal land in the US Pacific Northwest that caused roughly 11.6 million acres to be reallocated from commodity production to biodiversity services (Kerkvliet et al. 2007) - to more carefully examine some of the propositions associated with the amenity-based model of economic development and the amenity migration literature. There are several critiques of the commodity-based model of economic development by scholars who question whether the economic effects of cutbacks in timber production on federal lands have been as bad as that model predicts (e.g., Power 1996; Goodstein 1999; Niemi et al. 1999). Yet few critiques of the amenity-based model exist in the literature.
Amenity migration to western rural counties is rising, and consequently it is becoming a topic of growing interest to those concerned with rural community development in the USA. Our purpose is not to advocate for one model over the other (we recognize both have limitations), but rather to examine more carefully the links between forest management policy, amenity migration, and community wellbeing. To date, related research has been conducted almost exclusively at the county or regional scales using secondary data. There has been little research on how land management policies change the natural amenity values of specific locations (Garber-Yonts 2004), or on the relation between public land management policy, amenity migration, and socioeconomic well-being at the community scale. This paper addresses this gap.

Our analysis focuses on three propositions that we believe are implicit in the amenity-based model of economic development, and much of the amenity migration literature associated with public lands in the western USA: land management policies that reduce commodity production and/or increase environmental protection (1) improve the natural amenity values of public lands; (2) increase amenity migration to communities near public lands; and (3) stimulate economic development and increase socioeconomic well-being in these communities. Although we focus on forests and nearby communities, our arguments also pertain to other rural areas in North America undergoing the transition away from natural resource-based economies. After reviewing relevant literature, providing background to our case example, and discussing methods, we address each of the propositions in turn, drawing on data from our case and related literature. We find that community-scale analysis provides a different picture of the relation between forest management policy, population growth, and socioeconomic change than the existing literature presents, challenging assumptions of the amenitybased model of development. We conclude by discussing the implications of our findings for land management policy and rural community development.

\section{Public Land Management, Amenity Migration, and Economic Development}

The Northwest Forest Plan case serves as one example within a larger debate about the relation between public land management, amenity migration, and economic development in the rural American west. There is no question that amenity migration has been occurring; population growth in nonmetropolitan (rural) western counties since the mid-1980s has been high and widespread, and caused mainly by changes in net migration (Shumway and Davis 1996; Cromartie and Wardwell 1999; Johnson and Beale 
1999). The majority of migrants surveyed cited quality of life rather than economics as their primary reason for moving to nonmetropolitan areas, with quality of life linked to the presence of natural amenities like scenery, outdoor recreation opportunities, environmental quality, and climate (Johnson and Rasker 1995; Judson et al. 1999; Rudzitis 1999).

A number of researchers have assessed the relation between county-level population growth and the presence of natural amenities, including public lands. McGranahan (1999) found that population growth between 1970 and 1996 in nonmetropolitan counties in the USA was greatest in those ranked high in natural amenities (good climate, water bodies and coastlines, varied topography). Shumway and Otterstrom (2001) found that population growth in the mountain west was concentrated in counties that were well endowed with natural amenities, had high percentages of federal land ownership, and were recreation and retirement destinations. Other researchers have found that counties containing federal lands (such as National Forest Service, National Park Service, and Bureau of Land Managementmanaged lands and wilderness areas) grew more quickly during the 1980s and 1990s than counties lacking these lands (Rudzitis and Johnson 2000; Lewis et al. 2002; Frentz et al. 2004; Holmes and Hecox 2004). Moreover, nonmetropolitan western counties containing protected federal lands (national parks, national monuments, wilderness areas, roadless areas) experienced much higher population growth between 1970 and 2000 than those that did not (Lorah and Southwick 2003).

The presence of public lands in western counties has also been positively correlated with economic growth (Rasker 2006). Several researchers have investigated whether federal land management policies emphasizing environmental protection versus resource extraction (logging, mining, and grazing) have different effects on economic growth. There is evidence that the presence of public lands managed for noncommodity values (as opposed to resource extraction) does not have negative effects on income and employment growth at the county or regional scales (Rasker and Hackman 1996; Duffy-Deno 1998; Goodstein 1999; Lewis et al. 2002, 2003; Rasker 2006). Evidence is mixed, however, regarding whether managing public lands for environmental protection rather than resource extraction is positively correlated with income and employment at the county scale.

Some researchers have found no evidence of a positive correlation between economic growth and public land management for non-commodity values (Duffy-Deno 1998; Lewis et al. 2002); others have. For example, Rasker and Hackman (1996) found that from the 1970s to the early 1990s, counties in northwestern Montana having public lands managed primarily for environmental protection (e.g., wilderness areas, national parks) had much higher levels of job and income growth than counties having public lands managed mainly for resource extraction, and that the resource extraction counties had higher unemployment levels and less economic diversity. Other researchers have also found that employment and income growth are positively and significantly correlated with the amount of federally protected lands in nonmetropolitan western counties (e.g., wilderness areas, national parks, national monuments, and roadless areas; Lorah and Southwick 2003; Holmes and Hecox 2004; Rasker 2006). Researchers acknowledge that the presence of public lands and how they are managed is only one of several variables correlated with economic growth in western counties, however (Booth 1999; Rasker 2006), and that correlation is different from causation (Lorah and Southwick 2003).

Four observations emerge from this literature review. First, there is an assumption that public lands managed for environmental protection have higher natural amenity values than public lands managed for resource extraction. Second, most studies of amenity migration and its economic effects rely on county-scale data when discussing population trends and socioeconomic conditions. They do not analyze trends at the community scale, where the impacts of amenity migration and public land management policy are most strongly experienced. County-scale analyses of socioeconomic indicators have been critiqued for masking trends and impacts from land management policy occurring at the community scale (Beckley 1998; Harris et al. 2000; Jackson et al. 2003). Third, most studies rely on quantitative data from secondary sources-particularly population, income, and employment data; assume that population growth is correlated with increased socioeconomic well-being; and make assumptions about well-being in rural communities on the basis of only two economic indicators - income and employment. Fourth, some natural amenities (such as mountains, water bodies, coastlines, and climate) generally change relatively slowly over time (Garber-Yonts 2004). It is unclear whether these are the natural amenities that draw migrants, or whether public land management policies that promote environmental protection are also drivers. Changes in forest management policy in the Pacific Northwest and socioeconomic change in forest communities there provide a setting in which some of these issues can be explored.

\section{Background to the Northwest Forest Plan Case}

Following World War II, increased demand for lumber caused the wood products industry to become a major economic sector in the west. To meet this demand, the US Forest Service rapidly accelerated its timber sales program in the 1950s and 1960s (Hirt 1994). In addition to supporting employment in the wood products industry, 
Fig. 1 Total timber harvested from national forests in the western states, 1957-2002. Data are for 15 western states including the Pacific, Rockies, and Great Plains states. They do not include Hawaii or Alaska

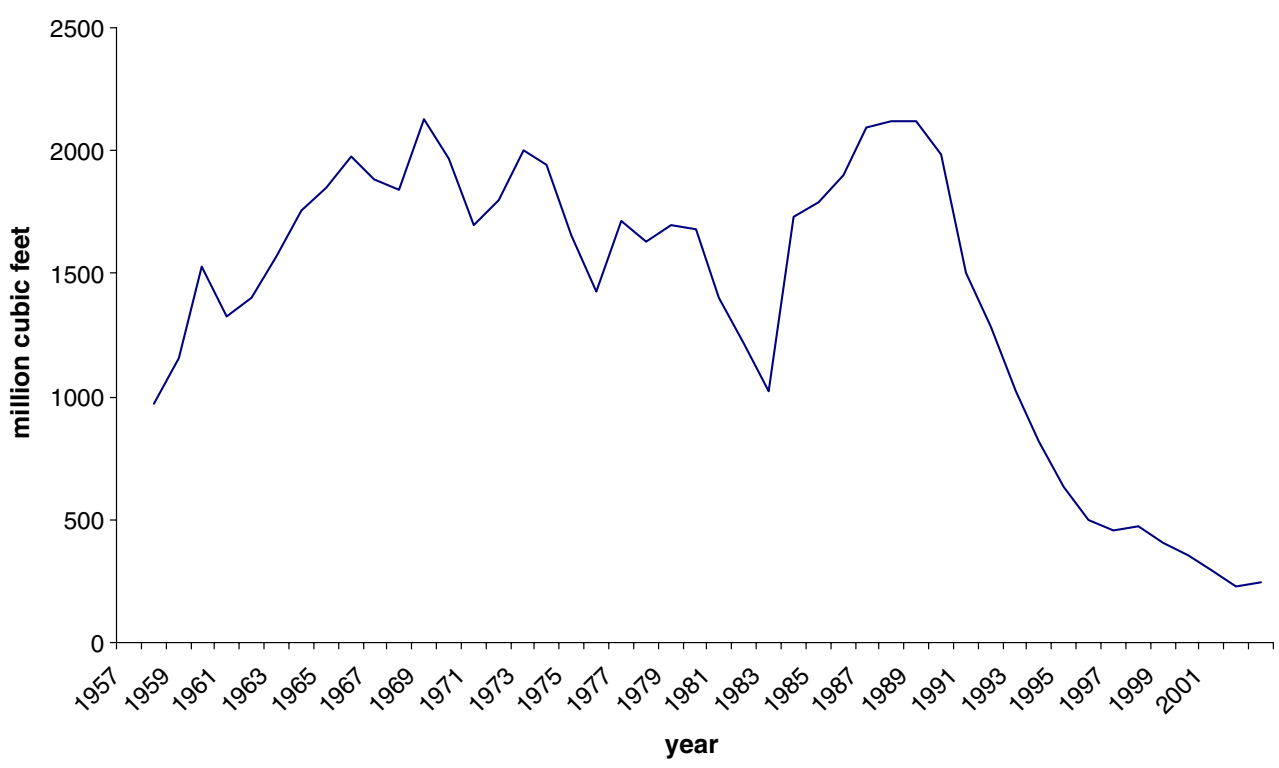

expanded federal timber sales and associated road infrastructure created employment opportunities for thousands of professionally trained foresters, engineers, and administrators in many rural communities throughout the Pacific Northwest. By the 1970s, however, the agency's focus on timber production at the expense of other uses and values led to growing environmental concerns, and the passage of several laws aimed at providing stronger environmental protections on federally administered lands (Hirt 1994). In the 1980 s, economic recession, mechanization, closure of inefficient mills, weaker demand for wood products, and the transfer of capital investment to other places combined to cause a drop in timber-industry employment (Goodstein 1999; Power 2006). At the same time, long-standing public concern over the environmental effects of logging practices, and demands to protect old-growth forests, erupted in intense controversy over timber harvesting on federallymanaged forest lands in the Pacific Northwest, the region where the majority of western timber was produced. The conflict resulted in a series of lawsuits in the late 1980s and early 1990s that effectively halted federal timber harvest in the Pacific Northwest, and led to development of the Northwest Forest Plan (Thomas et al. 2006). The effects of these political and economic shifts on timber production from national forests in the west are reflected in Fig. 1.

The Plan aimed to provide "...a sustainable level of human use of the forest resource while still meeting the need to maintain and restore the late-successional and oldgrowth forest ecosystem" (USDA and USDI 1994: 26-27). It represented a new approach to land management on 24 million acres of Forest Service and Bureau of Land Management-managed lands in western Washington, western Oregon, and northwestern California within the range of the northern spotted owl (Strix occidentalis caurina) that em- braced the principles of ecosystem management (Fig. 2). The Plan relied on two core strategies to enhance environmental protection. One strategy aimed to protect old-growth forests by establishing reserves and restricting timber harvest levels

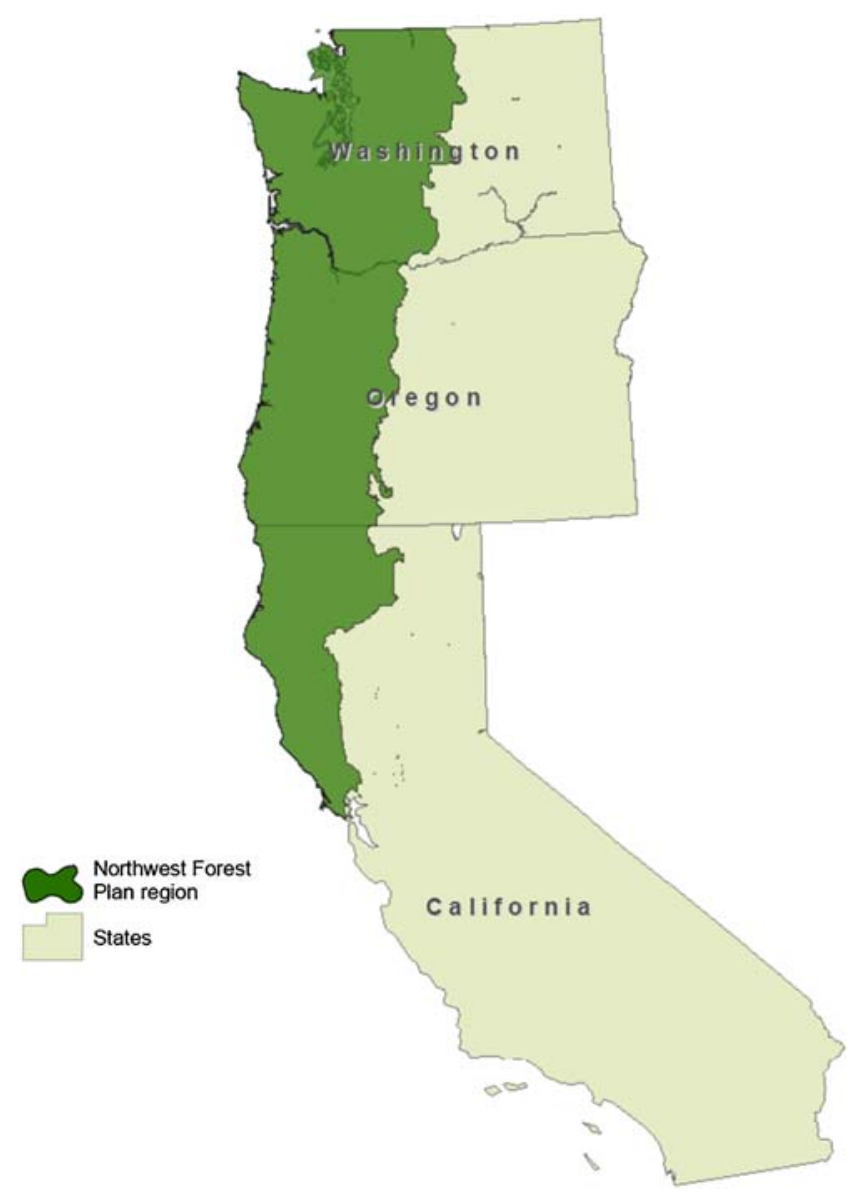

Fig. 2 The Northwest Forest Plan area 
and locations. The second strategy was to implement a region-wide aquatic conservation strategy containing management standards and guidelines designed to protect aquatic and riparian ecosystems by establishing a network of riparian reserves, reducing road densities, restoring key watersheds, and restricting human activities such as timber harvesting, grazing, mining, hiking, and camping in riparian zones (Reeves et al. 2006). Under the Plan, the annual average timber harvest from federal lands in Oregon and Washington dropped from 38\% of the total between 1965 and 1989, to $5 \%$ by 2000 . Between 1990 and 2000, primary wood products employment decreased by 30,000 jobs in the Plan area, with 11,800 of these jobs lost because of cutbacks in federal timber harvesting (Phillips 2006).

There was widespread concern in the Pacific Northwest over how job loss in the wood products sector resulting from changes in the industry and the Northwest Forest Plan would affect "forest dependent communities" (defined by the Forest Service as those having at least $10 \%$ of total employment in the wood products sector, with local wood processing firms using at least $50 \%$ federal timber). Negative effects included significant social, economic, and psychological hardship for workers and their families resulting from reduced job security and benefits; declining wages and occupational status; the breaking of social bonds held with other workers, the firms that employed them, and their communities; the stress of having to relocate; and the loss of occupational identity and a way of life (Carroll 1995; Daniels et al. 2000; Kusel et al. 2000; Helvoigt et al. 2003). Forest communities that experienced mill closures during the 1990s were found to have, on average, higher unemployment and household poverty rates in 2000 than in 1990 , and were not doing as well socioeconomically as communities where mills had not closed (Wilson 2003). These impacts occurred in spite of the fact that many communities that lost mills increased in population during the 1990s (Harris et al. 2000). Other researchers have argued that despite negative effects in some places, the shift in federal forest management policy did not have negative economic effects overall because employment growth in the Pacific Northwest during the 1990s far outweighed any negative regional economic impacts from reduced timber production on federal forest lands (Goodstein 1999; Power 2006). The total number of jobs in the Plan area grew by an annual average of about 130,000 jobs between 1990 and 2000 (Phillips 2006).

How specific communities were affected by the Plan was conditioned in part by their histories and social composition. Some communities were largely products of the post World War II federal timber boom, and had limited capacity to diversify their economies in the wake of declining timber harvests. Other communities were thriving long before the post World War II federal timber boom, and had much greater economic resilience when faced with declining federal timber supplies. This pre-existing variability conditioned the varied outcomes described and analyzed below.

\section{Methods}

The data we used to address the propositions that federal forest management policies that reduce timber production and/or increase environmental protection (1) improve the natural amenity values of forests, (2) increase amenity migration to forest communities, and (3) stimulate economic development and increase socioeconomic well-being in forest communities came from a large-scale, multiyear assessment of the biophysical and socioeconomic effects of the Northwest Forest Plan ten years after its implementation. Biophysical monitoring data were collected for older forest ecosystems (Moeur et al. 2005), aquatic and riparian ecosystems (Gallo et al. 2005), northern spotted owls (Lint 2005), and marbled murrelets (Brachyramphus marmoratus; Huff et al. 2006) on federal lands in the Plan area. Socioeconomic monitoring data were collected for nonmetropolitan communities in the Plan area (Charnley 2006a). The authors were active participants in the socioeconomic monitoring module. This module was not designed to test hypotheses relating to the effects of changing federal forest management policy on amenity migration, but rather, to understand these effects on community well-being. Nonetheless, our data are relevant for exploring propositions about these links.

Quantitative data regarding trends in recreation opportunities on federal forest lands in the Plan area between 1990 and 2003 were obtained from Forest Service and Bureau of Land Management (BLM) databases (see Charnley 2006b for more detail). These data were analyzed at both the forest unit and regional scales. In addition, we analyzed quantitative data on socioeconomic conditions at the communitylevel derived from the 1990 and 2000 US censuses. These data were also aggregated to the regional level to allow for comparison of changes in regional and national population.

We used US Census data to develop a community-level unit of analysis for the Plan region, which spans 72 counties. We aggregated 7,776 block groups (the smallest census geography for which all socioeconomic data are available) from the 1990 census into 1,314 nonmetropolitan communities that represent all people who reside there (Donoghue 2003). ${ }^{1}$ Block-group boundaries, particularly in

\footnotetext{
${ }^{1}$ The analysis does not include the 10 metropolitan areas in the region, namely San Francisco, Santa Rosa, and West Sacramento, California; Portland, Eugene, and Salem, Oregon; and, Bremerton, Richland-Kennewick-Pasco, Seattle, and Tacoma, Washington.
} 
rural areas, followed roads, telephone lines, fences, streams, and other geographic features and did not necessarily coincide with socially meaningful geographic places. Block groups were then aggregated into more meaningful units of analysis to better represent actual communities by combining geographic information system analysis with visual verification. Analysis and verification included information about roads, school districts, population size, public lands, census designations, and other spatial and demographic features.

The US Census modified the 1990 block group boundaries for the 2000 census. To make community socioeconomic data comparable from one decade to the next, we approximated the spatial allocation of population and housing by estimating the proportion of the population in the 2000 block groups that overlapped with the 1990 block groups. Proportions were calculated for each of the 2000 census block groups that overlapped the 1,195 community aggregations. They were developed by calculating the proportion of the population or housing of each 2000 block (the smallest census geography containing on average 100 people) found in each community. The 2000 community block populations were grouped and totaled by block group, producing 2000 block group populations within the communities. The 2000 block group community populations were divided by the total 2000 block group populations, producing the proportion of the 2000 population in each community. These proportions were used as multipliers for 2000 socioeconomic data so that these data approximated the same 1,314 community boundaries defined by aggregating the 1990 block groups. More information about defining the community-level unit of analysis and the census block group aggregation process is available in Donoghue (2003) and Donoghue and Sutton (2006).

Calculations of in- and out-migration using this communitylevel unit of analysis (aggregations of census block groups) were not possible. Therefore, we used change in population between 1990 and 2000 as a proxy for in- and outmigration, with the assumption that natural increase was close to the national average of $3.4 \%$ for nonmetropolitan counties (Johnson and Cromartie 2006). Although population change indicated the magnitude of change in population in a given community, we relied on qualitative data to better understand the extent of in- versus out-migration in a sample of case-study communities.

We also developed a community socioeconomic wellbeing index comprised of six census indicators that we used as a proxy for measuring change in community socioeconomic well-being between 1990 and 2000. The six census indicators were employment diversity, percent unemployment, percent of people living below the poverty level, household income inequality, percent of population 25 and older having a BA degree or higher, and average travel time to work. We conducted principal component analysis on about 50 variables to reduce the dataset to factors that contributed to high variation in the dataset. We then narrowed the dataset to a dozen variables that reflected the economic health of community members, such as unemployment, poverty, and income, and we looked for indicators that reflected other dimensions of community life. One basic assumption of the construct was that wellbeing could be enhanced or reduced. Thus indicators such as race, that did not clearly contribute in a positive or negative way to community socioeconomic well-being, were eliminated. The index combines social and economic variables into a single numeric score, while retaining the meaning of underlying variables. To see how the six indicators of the socioeconomic well-being index differed for communities by location (see below), we compared means, using two-sample t-tests, assuming unequal variance. Donoghue (2003) and Donoghue and Sutton (2006) provide more information about the socioeconomic wellbeing measure.

We divided the 1,314 communities in the region into two groups for analysis purposes. One group, referred to here as "forest communities", consists of 750 communities that lie within five miles of Forest Service and BLM lands. The second group, 564 communities, consists of those located more than five miles from Forest Service and BLM lands. We chose five miles because during the course of the socioeconomic monitoring project, federal land managers indicated that communities ten miles away from a particular federal forest, in general, were not considered as having primary connections to a forest, and a radius of fewer than five miles did not consistently include communities with connections to a forest. We compared change in population, median household income, poverty, unemployment, and socioeconomic well-being for both groups to assess whether there were differences between them. Community location in relation to federal forest lands serves as an indicator of natural amenity values because communities closer to federal forests presumably have easier access to nearby recreation opportunities, better scenic quality, more open space, and better environmental quality than those farther away.

Qualitative data were gathered from a sample of five federal forests and 17 forest communities associated with them in the Northwest Forest Plan area (Fig. 3). A total of 96 agency employees and 309 community members were interviewed between 2003 and 2005 to discuss changing social and economic conditions in their communities since 1990, the effects of the Plan on these conditions, and Plan effects on environmental conditions on nearby federal forests. The sample forests were purposefully chosen to represent a range of biogeographic conditions in the Plan 
Fig. 3 Sample case forests and associated communities

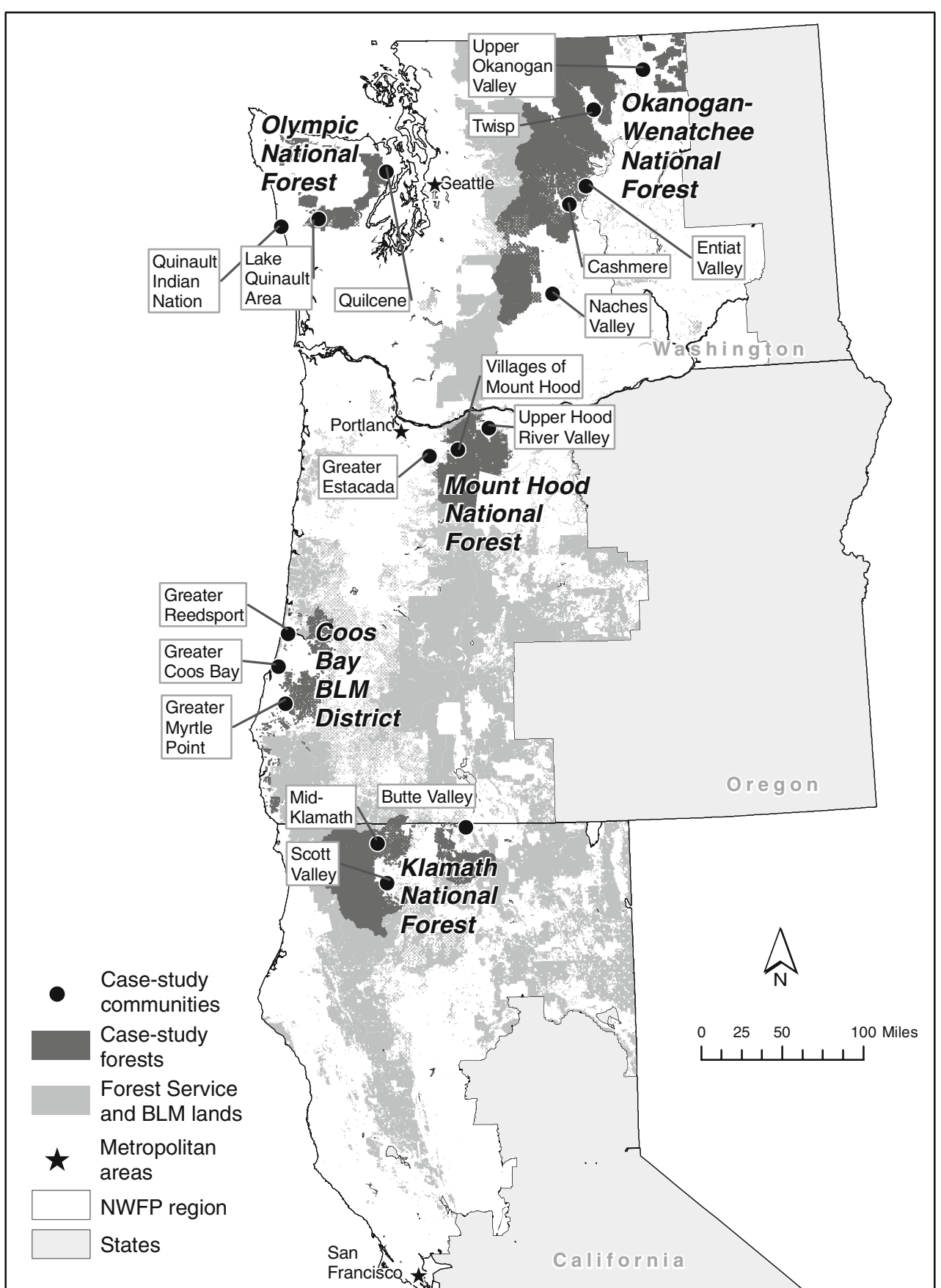

area. Sample communities around each forest were chosen randomly.

Community interviewees were purposefully chosen according to a set of criteria that included living locally since the early 1990s; hence the majority were long-term residents rather than recent migrants. Long-term residents were preferred because they could speak to the effects of the Plan-implemented in 1994-on their communities. These interviewees included individuals from a variety of occupations and social positions who had different viewpoints on forest management and economic development.
The precise mix varied by community, but typically included employees or members of timber companies (large and small), nontimber forest products businesses, environmental and watershed conservation organizations, recreation associations, mining companies, tourism-related businesses, fish and wildlife agencies, economic development agencies, tribal agencies, migrant worker organizations, school districts, municipal and county politicians, real estate associations, rancher and farmer associations, and social service agencies. This sampling strategy was essential for capturing the diversity of views held by long-term 
residents. However, a limitation of this approach was that it largely overlooked the views of recent migrants. Most agency employees interviewed were decision-makers and program managers or specialists, many of whom had worked at the same location since the 1990s.

Among other questions, community members and agency employees interviewed were asked: (1) Did the Plan protect the forest values and environmental qualities associated with older forest and aquatic ecosystems? (2) How did the Plan affect recreation opportunities and forest conditions on federal forest lands? (3) How has the population size and composition of your community changed over time, and what factors have caused people to leave or move into your community? (4) What other social and economic changes have taken place in your community since the Plan was implemented and what is causing these changes? Matrices containing information from the interviews were developed to identify patterns in the data set relating to the propositions. We also examined census data for the 17 sample communities to compare change in socioeconomic indicators at the regional and community scales. Charnley (2006a) contains a more detailed discussion of these methods.

To assess proposition 1 regarding the effects of federal forest management policy on the natural amenity values of forests, we used a combination of published data from the Northwest Forest Plan biophysical monitoring modules, and interview data from the socioeconomic monitoring module. To address propositions 2 and 3 regarding the effects of federal forest management policy on amenity migration and associated community economic development and socioeconomic well-being, we used US Census data and interview data. We also draw on other studies relating to amenity migration and the Northwest Forest Plan in evaluating our propositions.

\section{Results and Discussion}

\section{Proposition 1: Federal Forest Management Policies that Reduce Commodity Production and/or Increase Environmental Protection Improve the Natural Amenity Values of Federal Forest Lands}

To examine the first proposition we looked at the effects of the Northwest Forest Plan on forest conditions and recreation opportunities, both important contributors to the natural amenity values of federal forest lands. The forest conditions we considered included the amount of oldgrowth forest, forest health, watershed conditions, and fish and wildlife. No trend data on scenic quality were available from the agencies.
Scientists who assessed whether the Plan led to an increase in old-growth forests on federal lands and enhanced habitat for associated species found positive results (Moeur et al. 2005). The total net recruitment of old-growth forest during the first decade of the Plan was over one million acres resulting from a decrease in the rate of loss of existing old-growth forest and the development of new areas of old-growth on most federal lands. This increase can be interpreted as improving natural amenity values because most Pacific Northwest residents surveyed place a high value on old-growth forest, and support its protection (Charnley and Donoghue 2006).

Although old-growth forests have increased in extent, forest conditions are problematic. Medium and large forests cover roughly one-third of the Plan area (Spies et al. 2006). About $75 \%$ of these forests are at risk from high-severity fire and insect and disease outbreaks, especially in drier biogeographic provinces (e.g., eastern Cascades, Klamath Basin). These provinces suffered large losses to fire (ranging from $1.4 \%$ to more than $14 \%$ of the total older forest area) during the first decade of the Plan. If these rates of loss continue, these areas could lose many of their existing older forests in coming decades (Spies et al. 2006).

Reduced Forest Service budgets linked to cutbacks in timber harvesting (Stuart 2006), the high cost of implementing surveys required by the Plan to protect rare and little-known species, and political pressure to reduce fuels in populated wildland-urban interface areas (Thomas 2003) have limited the Forest Service's ability to carry out measures to protect older forests from fire. If fuels reduction projects in reserves included the removal of some merchantable timber, the revenues generated could be used to conduct additional fuels treatments there, helping maintain old-growth habitat (Spies et al. 2006). Instead, commercial timber harvesting in reserves is prohibited by the Plan, and timber harvest to generate funds for forest restoration has been controversial, and seldom occurred.

Pacific Northwest residents surveyed consistently express the view that active forest management is needed to improve forest health (Charnley and Donoghue 2006). Similarly, a key theme that emerged from interviews in the 17 communities was a belief that active forest management using silvicultural treatments improves and maintains forest health. Many interviewees identified forest health and risk of fire as top issues of concern. Yet many believed the Plan had resulted in a lack of management activity, causing forest health to deteriorate. Signs of poor forest health cited included the spread of tree-attacking insects and fungi, resulting in large expanses of forest covered with dead and dying trees; a buildup of understory fuels; and densely stocked young conifer stands, particularly in old clearcuts. These conditions were perceived as greatly increasing the risk of fire, especially on the drier Klamath, Mt. Hood, and 
Okanogan-Wenatchee National Forests. Many community members voiced concern about the negative ecological impacts of fires, such as widespread air pollution, increased soil erosion, the destruction of wildlife, and the loss of forest habitat. They also expressed concern about its potential effects on scenic quality, recreation, tourism, and the safety of their homes and property.

Community members had much more positive views about the watershed restoration and stream enhancement activities associated with the Aquatic Conservation Strategy. They cited improved fish and wildlife habitat, increased salmonid populations, reduced erosion along streams, and decreased sedimentation in local streams as examples of positive Plan effects. Monitoring of aquatic and riparian ecosystem conditions during the first ten years of Plan implementation (Gallo et al. 2005) supports these perceptions. Absent the Plan, timber harvesting and road building would likely have caused watershed conditions to decline, continuing a trend from preceding decades (Reeves et al. 2006). Instead, the number of watersheds showing improved conditions during the decade was much higher than the number in which conditions declined. Factors associated with improvements in watershed condition were an increase in the number of large trees in riparian areas, a decrease in timber harvesting and clearcutting in riparian areas, and road restoration and decommissioning projects (Gallo et al. 2005; Reeves et al. 2006).

Recreational activities like hiking, camping, hunting, fishing, gathering, and visiting cultural sites are important natural amenity values associated with federal forest lands. Not only do local residents and visitors enjoy these activities; many forest communities now look to recreation and tourism to provide local economic development and diversification opportunities in the absence of timber. Monitoring data indicate that some kinds of recreation opportunities increased under the Plan (e.g., recreating in unroaded and nonmotorized settings); some opportunities decreased (e.g., roaded recreation, some activities in riparian areas); and others showed little change (e.g., number of ski areas; Charnley 2006b). An important factor contributing to a decline in recreation opportunities was diminished road access for a wide range of recreational uses. In Oregon and Washington total road mileage on Forest Service lands decreased by 1,943 miles between 1990 and 2003, and roads maintained for passenger car access decreased from $21.7 \%$ to $15.8 \%$ of all system road miles (Charnley 2006b). On Oregon's BLM districts, road mileage decreased by 3,107 miles between 1999 and 2003 . Reduced road access to federal forests in the Plan area was not solely a result of the Plan, but the Plan contributed by causing a shortage of funding for road maintenance, which previously came from the timber program; creating restrictions on road construction and reconstruction in reserves; reducing demand for roads associated with timber sales; and emphasizing watershed restoration, which called for reducing road density.

Community interviewees expressed mixed views about the impacts of the Northwest Forest Plan on recreation opportunities on nearby forests. In the Coos Bay area, most community members stated that recreation opportunities on BLM lands had increased substantially. Many of these opportunities were tied to newly developed or refurbished trails, interpretive sites, environmental education programs, boat ramps, marinas, and campsites. Others, such as improved fishing opportunities, were linked to the implementation of large-scale fish and stream enhancement projects. On Forest Service lands, some interviewees also described improvements in recreation opportunities such as expanded trail systems, more roadless areas, the preservation of open space, and improvements in scenic quality because of reduced timber harvesting, especially clearcutting. However, most interviewees described negative Plan impacts on natural amenity values linked to recreation. On national forest lands, most of the unfavorable comments centered on the Forest Service's lack of capacity to maintain existing recreation infrastructure and to manage growing recreation demands. They also noted a decline in the quality of big game hunting due to the reduction in clearings associated with large-scale timber removal, congestion and overcrowding at recreation sites accessible by road, and concerns about vandalism and public safety due to Forest Service downsizing, meaning reduced patrolling of wilderness and off-road areas. Forest Service units in the Plan area lost $36 \%$ of their workforce between 1993 and 2002 (Stuart 2006).

The difference in recreation investments on Forest Service and BLM lands can largely be explained by differences in Plan impacts on agency budgets. Forest Service unit budgets in the Plan area dropped by an average of 35\% between 1993 and 2003, while BLM unit budgets rose by $22 \%$ during this period (Stuart 2006). Forest Service budgets are tied to the timber program; BLM budgets are not. Consequently, reduced timber harvesting under the Plan has led to deterioration of some recreationrelated amenity values on national forests.

In sum, the Northwest Forest Plan improved some natural amenity values associated with forest conditions in the Plan area, such as clean water, fish habitat, scenic quality, and old-growth forest. It has threatened others, however. Forest health declined in some places, posing a risk of uncharacteristically severe wildland fire that threatens older forests in dry regions in particular, the health and safety of neighboring landowners, and natural amenity values such as clean air, recreation, tourism, and scenic quality. The Plan contributed to an increase in some recreation-related natural amenity values, but caused a 
decrease in others. Thus, one cannot assume that forest management policies designed to promote environmental protection will automatically enhance the natural amenity values of forests, thereby drawing people to nearby communities and driving amenity-based economic development. Instead, they can adversely affect natural amenities in unanticipated ways.

Proposition 2: Forest Management Policies that Reduce Timber Production and/or Increase Environmental Protection Increase Amenity Migration to Forest Communities

At the regional scale, the 72 counties in the Northwest Forest Plan area experienced a $19.8 \%$ increase in overall population, growing from 8.57 million to 10.26 million people between 1990 and 2000 (Donoghue and Sutton 2006). This increase was considerably higher than the growth rate for the United States population, which was 13.2\% between 1990 and 2000. The 1,314 nonmetropolitan communities in the Plan area as a whole also increased in population during this time period from a total of 4.13 million to 4.98 million, an increase of $20.6 \%$. Population growth resulting from natural increase between 1990 and 2000 in nonmetropolitan counties nationwide was 3.4\% (Johnson and Cromartie 2006), an indicator of the magnitude of net migration that occurred in the Plan area.

Kerkvliet et al. (2007) analyzed the relation between net migration rates and federal land managed for conservation versus commodity production in Northwest Forest Plan area counties. Between 1994 and 2003 (the first decade after Plan implementation) they found no significant correlation between county net migration rates and the amount of Forest Service and BLM land allocated to protected versus extractive uses in a county. Our analysis found that population increase in forest communities (those within five miles of a federal forest) was $18.9 \%$ between 1990 and 2000 , compared to a $23.5 \%$ increase for communities farther from federal forests.

Not all communities increased in population. Overall, about one fifth of Plan-area communities (275) lost population between 1990 and 2000 (Table 1). Of these,
$176(64 \%)$ were forest communities. The communities that lost population tended to be fairly small, about $80 \%$ of them having populations between 250 and 2,000 in 2000 . Of the communities that increased in population, $50 \%$ grew at a rate that was below the $20.6 \%$ increase in population for all nonmetropolitan communities, and $60 \%$ of these were forest communities. The remaining $50 \%$ grew faster than the regional average; of these, half were forest communities and half were not (Table 1).

Community-scale population data show that many, but not all, nonmetropolitan communities are experiencing population growth. For the $21 \%$ of communities that lost population, the logic of amenity-driven economic development does not apply. The fact that forest communities increased in population at a slower rate than did those located farther than five miles from federal forests implies that communities having the closest ties to federal forests experienced less population growth through in-migration. According to the amenity-based model, they would also have benefited less from amenity-driven economic development. Nevertheless, some forest communities experienced high rates of in-migration.

Analysis of population change between 1990 and 2000 in the 17 sample communities provides insight into what caused local population change. Just under half of the communities (seven) experienced a decline in overall population, with four of them experiencing a decline in population of between $11 \%$ and $22 \%$ (Table 2). The other ten communities experienced an increase in overall population. However, among the communities undergoing population growth, the rate of increase varied from under $1 \%$ in Scott Valley to more than $20 \%$ in five communities. One of these-Villages of Mt. Hood-had an overall population growth rate of $50 \%$.

Three of the communities with population growth over $10 \%$ (Greater Estacada, Upper Hood River Valley, and Villages of Mt. Hood) are located within commuting distance of the Portland metropolitan area, and two are located on the slopes of Mt. Hood, a prime recreation destination for the Portland metro area. The other five communities with population growth over $10 \%$ are all located on the eastern front of Washington's Cascade

Table 1 Percent change in population, 1990 to 2000

\begin{tabular}{lrr}
\hline Percent change in population & $\begin{array}{l}\text { Forest Communities } \\
(<5 \text { mi. from fed. forest })\end{array}$ & $\begin{array}{r}\text { Nonforest Communities } \\
(>5 \text { mi. from fed. forest })\end{array}$ \\
\hline Population decrease (-74\% to 0\%) & $176(64 \%)$ & $99(36 \%)$ \\
Population increase, below regional average (0-20\%) & $309(60 \%)$ & $209(40 \%)$ \\
High population increase (20-75\%) & $244(52 \%)$ & $228(48 \%)$ \\
Very high population increase (76-200+\%) & $21(43 \%)$ & $28(57 \%)$ \\
Total & $750(57 \%)$ & $564(43 \%)$ \\
\hline
\end{tabular}


Range, within a half day's drive or less from the Seattle metropolitan area and within commuting distance of the towns of Yakima and Wenatchee. These five communities are also the only ones located east of the Cascade Range in Washington and Oregon, where the climate is notably sunnier than on the west side of the Range. The seven communities with declining populations are all small, and except for Quilcene, geographically isolated from the Northwest's large metropolitan centers.

Interviews with community residents indicated that all of the communities, including those with declining populations, had experienced in-migration between 1990 and 2000. The kinds of people who moved in and out varied by community. When asked who had moved into their communities, interviewees in most of the communities mentioned retirees and older adult workers (primarily white collar workers employed in the services sector) as being among the newcomers. In some communities, interviewees indicated that in-migrants included Latinos, often farmworkers or blue collar workers. In others, many low-income residents who were reported to be welfare recipients had moved in. In communities with tribal administrative offices, interviewees noted an increase in the number of Native Americans. Interviewees in all of the communities indicated that most of those who migrated out of the area during this period were working class families (with at least one wage earner, usually the husband, working in timber-related jobs) with children still at home, or young single adults.

Table 3 summarizes the factors that key informants in the 17 communities mentioned as important drivers of inmigration. Natural amenity values have played a role in attracting newcomers to many rural communities located in the Northwest Forest Plan region. However, informants also listed a variety of other factors that drew new residents. For example, the out-migration of timber workers and their families had left housing gluts, resulting in low prices for land and houses through the late 1990s that drew low and fixed-income residents. In communities with large Latino populations, such as the Upper Hood River Valley, Naches Valley, and Cashmere, the availability of work in farming, horticulture, food processing, nurseries, cedar shake production, and nontimber forest product harvesting was an important draw for new Latino residents. Also, migrant workers are increasingly taking up residence in rural communities and bringing their families to live with them.

Interestingly, very few of the interviewees mentioned change in forest management policy from timber production to environmental protection as a factor influencing inmigration to their communities. Nearly all of them mentioned it as the major factor driving out-migration, however. According to interviewees, job loss in the wood products industry led to out-migration for two reasons: people who lost jobs had to find new jobs elsewhere, so families moved; and, young people growing up locally had fewer job opportunities at home, so had to move away in search of them.

All 17 communities are in or near forested environments. Many are located just minutes from hiking trails, wilderness areas, fishing streams, kayaking and rafting areas, and campgrounds. A few are just a short drive away from spectacular coastlines or major ski resorts. In short, all of the communities are surrounded by an abundance of natural amenity values, including scenic landscapes, outdoor recreation opportunities, and relatively unpolluted air and water. Nevertheless, some are better endowed with natural amenities than others. For example, communities situated in
Table 2 Change in population 1990-2000, sample communities

\begin{tabular}{lrrr}
\hline Community & Population in 1990 & Population in 2000 & $\begin{array}{c}\text { Percent change } \\
\text { population, 1990-2000 }\end{array}$ \\
\hline Butte Valley & 1,908 & 1,885 & -1.21 \\
Cashmere & 6,045 & 7,576 & 25.30 \\
Coos Bay & 27,851 & 28,596 & 2.67 \\
Entiat Valley & 1,548 & 2,101 & 35.70 \\
Estacada & 8,396 & 9,315 & 10.95 \\
Lake Quinault & 1,542 & 1,471 & -11.77 \\
Mid-Klamath & 2,117 & 1,660 & -21.59 \\
Mt. Hood Villages & 2,445 & 3,670 & 50.00 \\
Myrtle Point & 5,383 & 4,927 & -8.47 \\
Naches Valley & 4,659 & 6,269 & 34.60 \\
Quilcene & 478 & 375 & -21.55 \\
Quinault Nation & 705 & 622 & -4.60 \\
Reedsport & 6,246 & 5,545 & -11.22 \\
Scott Valley & 5,100 & 5,126 & 0.51 \\
Twisp & 2,445 & 2,894 & 18.40 \\
Upper Hood River & 3,752 & 4,228 & 14.29 \\
Upper Okanogan & 10,729 & 13,231 & 23.30 \\
\hline
\end{tabular}


Table 3 Reasons for in-migration, sample communities

\begin{tabular}{|c|c|c|}
\hline Community & $\begin{array}{l}\text { Overall population } \\
\text { growth? }\end{array}$ & Factors contributing to in-migration \\
\hline Butte Valley & No & $\begin{array}{l}\text { Inexpensive real estate, low cost of living, clean air and water, scenic beauty, } \\
\text { recreation opportunities, easy commute to Klamath Falls, Latinos attracted } \\
\text { by farmwork }\end{array}$ \\
\hline Cashmere & Strong & Easy commute to Wenatchee, Latinos attracted by food processing work \\
\hline Coos Bay & Low & $\begin{array}{l}\text { Medical and retail services, inexpensive real estate, small town feel, scenic } \\
\text { beauty, clean air }\end{array}$ \\
\hline Entiat Valley & Strong & Inexpensive real estate, easy commute to Wenatchee, recreation opportunities \\
\hline Estacada & Strong & $\begin{array}{l}\text { Inexpensive real estate, easy commute to Portland, rural life, nursery work } \\
\text { for Latinos, open space, recreation opportunities }\end{array}$ \\
\hline Lake Quinault & No & $\begin{array}{l}\text { Scenic beauty, recreation opportunities, Latinos attracted by work in cedar } \\
\text { shake and floral greens industries }\end{array}$ \\
\hline Mid-Klamath & No & Inexpensive real estate, low cost of living, scenic beauty, recreation opportunities \\
\hline Mt. Hood Villages & Strong & Inexpensive real estate, recreation opportunities, easy commute to Portland, rural life \\
\hline Myrtle Point & No & $\begin{array}{l}\text { Medical and retirement services, small town feel, easy commute to Coos Bay, } \\
\text { inexpensive real estate, clean air }\end{array}$ \\
\hline Naches Valley & Strong & Good schools, easy commute to Yakima, rural setting \\
\hline Quilcene & No & Inexpensive real estate, easy commute to Bremerton, scenic beauty \\
\hline Quinault Nation & No & New job opportunities linked to tribal self-governance \\
\hline Reedsport & No & Inexpensive real estate, marina facilities \\
\hline Scott Valley & Very low & Inexpensive real estate, better quality of life \\
\hline Twisp & Strong & Natural beauty and recreation opportunities \\
\hline Upper Hood River & Strong & Clean air and water, scenic beauty, quiet, recreation opportunities \\
\hline Upper Okanogan & Strong & $\begin{array}{l}\text { Inexpensive real estate, Latinos attracted by opportunity to purchase } \\
\text { inexpensive orchards, Canadians attracted by the quiet rural setting }\end{array}$ \\
\hline
\end{tabular}

the rain forest on the west side of the Olympic National Forest have climates that do not appeal to prospective longterm residents, according to some community interviewees from the Olympic Peninsula (the area receives roughly 100 inches of rain annually). Others, such as communities around the Coos Bay District, do not have popular recreational draws like ski areas. Moreover, natural amenities are not the only values that draw people to communities; social and economic amenities are also important (Rasker 2006). Some communities, like those located near the Klamath National Forest, are remote from major population centers and associated social amenities. And many very small towns, such as Quilcene and the Lake Quinault Area, lack the retail and medical services that some of today's amenity migrants are looking for (Rasker 2006). Several interviewees from the Klamath National Forest communities stated that younger retirees who moved there early in their retirement often moved away as they aged and needed to be close to medical services.

Evidence from the Northwest Forest Plan case indicates that forest management policy that curtails resource extraction and promotes environmental protection does not drive population growth in all communities, even if it does so at the county scale. Communities have different natural amenity endowments, and thus will draw people differentially. Social and economic amenities unaffected by forest management policy also play a role in influencing amenity migration. And, where in-migration has occurred, the reasons are many and not all related to natural amenities or land management policy. We found that communities within five miles of a federal forest overall experienced lower population growth rates than those farther away, and that more forest communities than other nonmetropolitan communities lost population between 1990 and 2000. We examine how forest communities fared from a socioeconomic standpoint in the next section.

Proposition 3: Forest Management Policies that Reduce Timber Production and/or Increase Environmental Protection Stimulate Economic Development and Increase Socioeconomic Well-Being in Forest Communities

At first glance, regional-scale analysis lends support to proposition 3. In the Northwest Forest Plan area as a whole, employment grew by $29 \%$ between 1990 and 2000, representing an increase of 1.4 million jobs, despite the fact that primary wood products employment declined by 30,000 jobs during the same period (Phillips 2006). Most of the job loss occurred in nonmetropolitan counties, however, where there are relatively few employment opportunities. In contrast, most of the growth in total employment occurred in metropolitan areas. Thus, new jobs were not necessarily 
Table 4 Change in community socioeconomic well-being scores, 1990-2000

\begin{tabular}{lccc}
\hline $\begin{array}{l}\text { Change in community socioeconomic } \\
\text { well-being, 1990-2000 }\end{array}$ & $\begin{array}{l}\text { Communities in Plan area } \\
(\%, n=1,314)\end{array}$ & $\begin{array}{l}\text { Forest Communities } \\
(<5 \text { mi. from fed. forest }) \\
(\%, n=750)\end{array}$ & $\begin{array}{l}\text { Nonforest Communities } \\
(>5 \text { mi. from fed. forest }) \\
(\%, n=564)\end{array}$ \\
\hline Decreased (<-3\% change) & 37 & 40 & 33 \\
Increased ( $>3 \%$ change) & 36 & 37 & 36 \\
Little change ( -3 to 3\% change) & 27 & 24 & 31 \\
\hline
\end{tabular}

created in the same places where jobs had been lost (Phillips 2006).

The highest employment growth was in the services sector (56\%; Phillips 2006). Jobs created in association with amenity migration are often in the services sector (English et al. 2000; Shumway and Otterstrom 2001). Although some services jobs pay well (Holmes and Hecox 2004), many jobs associated with natural amenities, recreation, and tourism are seasonal and very low wage (McKean et al. 2005). Even if people living in high-growth amenity and recreation counties have higher incomes, these may be offset by higher costs of living (English et al. 2000; Hunter et al. 2005). In 2000, average annual wages in manufacturing in the Northwest Forest Plan area were $\$ 55,000$; in the services sector they were $\$ 37,000$ (Phillips 2006). Thus, even if new jobs in the services sector were created in communities that lost jobs in the wood products industry (the manufacturing sector), these jobs were unlikely to have paid as well as the jobs that were lost. Moreover, workers' skills are not necessarily transferable across employment sectors.

A second glance based on deeper investigation of economic and socioeconomic trends at the community scale reveals a more detailed picture of the relation between forest management policy and socioeconomic change. Our data indicate that as with population, socioeconomic indicators showed mixed trends at the community scale. The socioeconomic well-being index (SEWB) served as a proxy for change in socioeconomic well-being in Plan-area communities. Table 4 shows change in the socioeconomic well-being scores of the 1,314 communities. Overall, only $36 \%$ of these communities increased in socioeconomic well-being between 1990 and 2000; 37\% decreased and $27 \%$ showed little change.

Comparison of change in SEWB from 1990 to 2000 between forest and nonforest communities found that $40 \%$ of the forest communities experienced a decrease in socioeconomic well-being scores, compared to $33 \%$ of the communities farther away. In addition, in 2000, a greater percentage of forest communities had scores in the low or very low categories $(36 \%)$ than communities that were farther away (19.3\%). In contrast, a greater percentage of communities farther away from federal forests had scores in the high or very high category (44.5\%) than forest communities (25.2\%; Donoghue and Sutton 2006). Many variables influence socioeconomic well-being in communities, and forest management policy is only one of them. Nevertheless, these indicators do not provide evidence of widespread, positive effects of shifting forest management policy from commodity production to environmental protection at the community scale in forest communities. As of 2000, on average, forest communities were not doing as well as nonforest communities (Table 5). Five of seven census indicators we examined (unemployment, poverty, median household income, household income inequality, and higher education) showed that conditions were significantly more favorable in nonforest communities. One indicator (employment by industry diversity) showed no significant difference. Only one (average travel time to work) was more favorable in forest than in nonforest communities. Yet forest communities presumably have higher natural amenity values than nonforest communities and experienced greater impacts from the Plan because of their location.

Table 5 Comparison of components of socioeconomic well-being index for forest and non-forest communities, 2000

\begin{tabular}{|c|c|c|c|}
\hline Indicator name, 2000 & $\begin{array}{l}\text { Forest Communities } \\
\text { ( }<5 \mathrm{mi} \text {. from fed. forest })\end{array}$ & $\begin{array}{l}\text { Nonforest Communities } \\
\text { ( }>5 \text { mi. from fed. forest) }\end{array}$ & Difference \\
\hline Employment by industry diversity & 0.895 & 0.898 & 0.003 \\
\hline Percent population 25 years and older having bachelor's degree or higher & 17 & 22 & $5^{*}$ \\
\hline Percent of the population unemployed & 8.1 & 6.3 & $1.8^{*}$ \\
\hline Percent of persons living below the poverty level & 13 & 10 & $3^{*}$ \\
\hline Household income inequality & 3.33 & 3.14 & $0.19^{*}$ \\
\hline Average travel time to work (min) & 24.6 & 26.6 & $2 *$ \\
\hline
\end{tabular}

$* P<0.01$ 
The amenity-based model of economic development predicts that population growth drives economic growth. We examined correlations between population growth and change in socioeconomic well-being at the community scale. If the amenity-based model of economic development holds true, one would expect to see socioeconomic well-being scores increasing in those communities experiencing population growth. Conversely, one would expect socioeconomic well-being to decline as population drops. Instead, we found no clear patterns.

Of the 521 communities in the region with the highest percent increase in population between 1990 and 2000 (greater than the regional average of $20.6 \%$ ), 37\% had lower socioeconomic well-being scores in 2000 than in 1990; 30\% experienced little change; and 32\% experienced increases in socioeconomic well-being (Table 6). At the other extreme, for the 275 communities that lost population, $34 \%$ decreased in socioeconomic well-being, $21 \%$ experienced little change, and $45 \%$ increased in socioeconomic well-being. Communities with declining populations and those with rapidly growing populations both experienced drops and increases in socioeconomic well-being.

Interview data support the finding that a complex relationship exists between amenity migration and community well-being. Interviewees identified both negative and positive dimensions to amenity migration in their communities. This was true in all communities regardless of how the SEWB measure changed, illustrating that social change is much more complicated than can be captured by these measures. Interviewee comments touched on four aspects of community well-being: the ability of communities to adapt to change, cultural identity, economic effects, and quality of life.

Table 6 Comparison of change in population and change in socioeconomic well-being, 1990-2000

\begin{tabular}{lr}
$\begin{array}{l}\text { Population change with change in socioeconomic } \\
\text { well-being }\end{array}$ & $\begin{array}{l}\text { Number of } \\
\text { communities }\end{array}$ \\
\hline Decrease in population $(-74 \%$ to $0 \%)$ & 275 \\
Decrease in SEWB ( -51 to $<-3$ points) & 92 \\
Little change in SEWB ( -3 to 3 points) & 59 \\
Increase in SEWB ( $>3$ to 44 points) & 124 \\
Population increased, but below regional average & 518 \\
(1-20\%) & \\
Decrease in SEWB ( -51 to $<-3$ points) & 198 \\
Little change in SEWB ( -3 to 3 points) & 136 \\
Increase in SEWB ( $>3$ to 44 points) & 184 \\
High to very high increase in population $(21-200+\%)$ & 521 \\
Decrease in SEWB ( -51 to $<-3$ points) & 194 \\
Little change in SEWB $(-3$ to 3 points) & 158 \\
Increase in SEWB ( $>3$ to 44 points) & 169 \\
Total & 1,314 \\
\hline
\end{tabular}

Views about the effects of amenity migration on community ability to adapt to change were decidedly mixed. Informants in many of the communities indicated that social tensions had increased with the arrival of amenity migrants, many of whom held views about natural resource management and economic development that differed substantially from those of longer-term community members. In some communities, such as Greater Estacada, Quilcene, and Upper Hood River Valley, tension over the direction of economic development substantially undermined community efforts to work together and find ways of adapting to declines in the wood products industry. On the other hand, informants in these communities and others indicated that newcomers brought with them new skills, expertise, and financial stability. Views on whether migrants contributed to community capacity were partly shaped by whether these newcomers were civic-minded and engaged in community improvement activities, or kept to themselves. Views about the benefits of a strong influx of retirees in communities such as Greater Reedsport and Greater Myrtle Point also varied. Some interviewees stated that retired residents were an important source of volunteer labor in civic projects, while others asserted that the replacement of families by older couples had drained the community of its lifeblood.

The loss of cultural identity associated with resourcebased lifeways such as forestry and ranching was a common feature in the communities. Much of the literature discussing the transition from natural resource to amenitybased rural economies appears to dismiss the timber legacy as unimportant; as though it did not matter if people can no longer make a living working in the woods, or in other ways tied to natural resources. We found that in the sample communities, a dominant concern among long-time residents was the lack of local, family wage jobs tied to natural resources. Many interviewees viewed forests as a place to work, and wanted to find new ways in which federal forests could provide local, family wage jobs that would enable them to remain in their communities, maintain family ties, and continue a way of life important to them.

From the standpoint of economic benefits, the picture is also mixed. Tourism and recreation have unquestionably been a stabilizing factor in many communities. A resident from the Lake Quinault Area described how important tourism was to his community: "One of the reasons there is a community here is because of tourism. If it wasn't for the lake and the beauty of the area, there wouldn't be a community here." But recreation and tourism were often controversial issues in the communities. Resistance in the Lake Quinault Area and many other sample communities to recreation and tourism was strong. One source of disgruntlement with these industries was the widespread perception that the jobs it provided were seasonal and poorly paid 
compared to jobs in the wood products industry. Community interviewees also had mixed perceptions of the economic benefits associated with amenity migrants themselves. For example, in Greater Myrtle Point — a community that has rapidly transformed into a retirement center-a building contractor noted that retirees could not stimulate economic growth the way that younger families who left in the 1990s could. He said, "We need entrepreneurs here, people who can see what we have and create something out of it that brings in jobs." Long-time residents in places that have become bedroom communities also questioned how much the influx of amenity migrants adds to the local economy. They noted that, unlike forestry workers, commuters live in their communities but work in nearby cities, where they do most of their shopping and spending, instead of at local stores. As a resident of Greater Estacada observed, "They're shoppin' at the Clackamas Town Centers, the Safeways, and the Fred Meyers - the big chain stores in town - they're not doin' it here."

Interestingly, analysis of income inequality data from the US Census found that between 1990 and 2000, there was a statistically significant increase in income inequality in forest communities, but no significant difference for communities farther away (Donoghue and Sutton 2006). This finding may reflect in-migration by wealthy amenity migrants, causing an increase in the gap between rich and poor households in forest communities. Income inequality is often a source of social tension (Wilkinson 1991).

Finally, quality of life issues were a concern. In communities close to urban areas, such as Upper Hood River Valley and Villages of Mt. Hood, the sheer numbers of newcomers, tourists, and recreationists, and the pollution, congestion, and crowding associated with them, threatens quality of life and jeopardizes long-term amenitybased development. As other authors have noted, amenity migration can undermine environmental quality as population growth and associated infrastructure development, combined with low density land use, lead to uncontrolled sprawl and habitat fragmentation (Vias and Carruthers 2005). Other concerns included fears that public lands would be locked up for recreational uses such as hunting, fishing, and camping, and unavailable for commodity production; and feelings that the mainly urban-based tourists disdained many of the values that long-time rural community members hold dear. Regarding out-migration and the splitting up of families associated with the loss of timber industry jobs, a resident from Butte Valley summed up the problem thus, "Economic substitution is insufficient. Money doesn't fix the loss of the family infrastructure."

In sum, with respect to the proposition that forest management policies that reduce timber production and/or increase environmental protection stimulate economic development and increase socioeconomic well-being in forest communities, we find that (1) socioeconomic wellbeing improved in some, deteriorated in some, and showed little change in other communities; (2) these changes were not correlated with population growth; and (3) there was no evidence that the Plan had widespread, positive effects in forest communities, which would have been more likely to experience amenity-driven economic development than nonforest communities; instead, SEWB indicators were generally less favorable there. Qualitative data indicate that amenity migration has had mixed effects on community capacity, cultural identity, economic conditions, and quality of life, some of which threaten both the natural and social amenities of nonmetropolitan communities.

\section{Conclusions}

We used the Northwest Forest Plan case to examine the propositions that public land management policies that reduce commodity production and/or increase environmental protection (1) improve the natural amenity values of public lands; (2) increase amenity migration to communities near public lands; and (3) stimulate economic development and increase socioeconomic well-being in these communities.

Regarding proposition 1, we found that the shift from timber production to environmental protection on federal forests in the Pacific Northwest caused some natural amenity values to improve and others to deteriorate. Thus, one cannot assume that forest management policies designed to promote environmental protection will also enhance the natural amenity values of forests that draw people to rural communities and allegedly drive economic development there. Instead, these policies can adversely affect some of the natural amenity values of forests in unanticipated ways.

For proposition 2, we found that not all nonmetropolitan communities experience population growth due to amenity migration - despite overall population growth in nonmetropolitan areas at the regional scale - even if they are close to federal forests that provide abundant natural amenity values and are managed predominantly for environmental protection. Assuming that natural resource management policies that favor environmental protection will lead to population growth in communities that were formerly natural resource dependent, and be a driver of economic development there, is an over-generalization commonly inferred by the amenity migration literature that analyzes population and economic growth at the county and regional scales.

Regarding proposition 3, community-scale analysis revealed that socioeconomic indicators improved in some nonmetropolitan communities following reductions in timber harvesting on federal forests, but deteriorated or 
showed little change in most communities. Statistically significant differences existed between socioeconomic indicators for communities within five miles of a federal forest, and those farther away; they tended to be less favorable in communities within five miles. These are the communities that presumably are higher in natural amenities. Change in community socioeconomic conditions was not correlated with population growth. Finally, qualitative data painted a mixed picture of the effects of amenity migration on community well-being. One limitation of this study is that it focused on the perspective of long-term residents rather than recent amenity migrants, which could have biased this picture.

These findings call into question some of the underlying assumptions of the amenity-based model of economic development as they relate to forest management policy. Although regional and county-scale analyses paint an optimistic picture, community-scale analysis shows that changing federal forest management policy from timber production to ecosystem management, biodiversity conservation, and protection of endangered species is not correlated with increases in population and socioeconomic well-being in many forest communities. Perhaps more time is needed for these effects to occur. Instead, we found that forest management policy affects different communities differently, depending on their individual characteristics and circumstances. Assuming that amenity migration will be a driver of population growth and economic development in communities affected by cutbacks in federal timber production may work for some, but not all, communities. Other development strategies will be needed. These findings stress the importance of community-scale analysis for understanding the relations between forest management policy and community well-being.

Our findings also stress the need for a more rigorous approach to understanding forest-community relations. Most studies that model population growth as a driver of rural economic development base their analyses on a small number of county-scale economic indicators, typically employment and income. These analyses ignore other indicators of community well-being, both quantitative and qualitative, masking many of the community-scale effects of changing federal forest management policy that are not all positive. For example, socioeconomic and population dynamics in forest communities are contributing to greater disparity in income among residents in ways that are rarely addressed in the amenity migration literature. Indicators such as poverty, education, and travel time to work reflect other dimensions of community well-being. And, qualitative data reveal aspects of community life that are difficult to model with secondary data, such as community leadership, social cohesion, and other factors that affect the ability of a community to adapt to change.
What are the implications of these findings for public land management policy and rural community development? Since the 1980 s understanding of the relation between forests and communities has evolved away from the notion of community stability, a foundation of the commodity-based model of economic development. Current thinking focuses instead on the concept of community resilience. Researchers have found that the greater the diversity of economic opportunities available in a community, the greater the ability of the community to adapt to change, with positive implications for socioeconomic wellbeing (Donoghue and Sturtevant 2007). Managing for multiple forest uses provides diverse economic opportunities for community residents - in the wood products industry, ranching, nontimber forest product harvesting, and the recreation and tourism industries-potentially contributing more to community resilience and socioeconomic well-being than managing for environmental protection to the exclusion of resource extraction.

We disagree with those who argue that "...the West's economic future lies not in extractive industries, but in industries that benefit from the presence of environmental amenities" (Lorah and Southwick 2003:268). Commodity production and environmental protection need not be mutually exclusive community development strategies. Just as land management policies that promote environmental protection do not necessarily enhance all of the natural amenity values of forests, land management policies that favor commodity production do not necessarily undermine them, and can potentially improve them. For example, timber harvesting can generate revenue needed to conduct ecological restoration work. Forest restoration and its byproducts (e.g., small-diameter wood, biomass) provide jobs in the woods, commodities, and business and employment opportunities in local communities while simultaneously enhancing the natural amenity values of forests. Forestbased jobs can be particularly important in places that are not experiencing population growth or amenity-driven development.

Researchers who support the amenity-based model of economic development often argue that this model moves beyond the jobs versus environment debate, to a jobs and the environment model (e.g., Goodstein 1999). The jobs they refer to however are typically in the services sector rather than the extractive industries. Does the kind of job matter? The response to this question typically centers on whether jobs in the services sector pay as well as jobs in natural resource sectors. Our findings suggest another dimension of job quality that is important, with implications for the environment and natural amenity values. Often community members we interviewed who had worked in the wood products industry expressed a deep care for the forests around them, held local ecological knowledge about 
them, and felt a sense of stewardship toward them. The loss of opportunities to work in the industry and implementation of the Northwest Forest Plan had caused many to disengage from forest management and stewardship activities, breaking one kind of connection between people and forests. The Forest Service is currently concerned about such lack of connection, with one if its top three priorities being connecting more people, especially kids, with nature (Forest Service 2008). Moreover, the loss of skilled workers and infrastructure following the decline of the wood products industry has created a shortage of agency and community capacity to engage in forest restoration, which is currently needed. Forest-based jobs help people maintain their connection to forests, valuable ecological knowledge about them, and a role for communities in forest stewardship, all of which have positive benefits for forests and forest communities. These jobs also help people maintain a way of life and cultural identity that are important to them.

Why are people moving to communities around public lands? Is it because they want to live near natural amenities like mountains, water bodies, and forests, or because of specific forest management policies? Our findings suggest that amenity migration to nonmetropolitan communities has more to do with the presence of public lands and the values they offer, than with the specific policies according to which they are managed. This is particularly so because natural amenities are only one of the things that draw people to rural communities; social amenities are also important. We believe in-migration is likely to influence forest management policy more than forest management policy influences in-migration. Many challenges are associated with population growth around public forest lands. These include increased recreation demands, increased potential for introducing invasive species, growing parcelization and habitat fragmentation on adjacent lands, and the need to reduce hazardous fuels and suppress fire in wildland-urban interface areas. Some researchers have begun to examine the implications of amenity migration for forest management policy (Kruger et al. 2008). More work on how to prevent amenity migration from undermining the natural amenity values of public lands is called for.

Lastly, our findings point to the importance of addressing the relation between forest management policy, amenity migration, and community well-being at the community scale to understand how rural community development strategies can be tailored to specific local circumstances. A one-size-fits-all approach, whether based on the commodity or amenity-driven model of economic development, is unlikely to meet the needs of many communities. Instead, a balanced, multiple use approach to public land management in the USA that recognizes the importance of diverse community development opportunities, the benefits of engaging local residents in land stewardship, and the value of maintaining a variety of connections between communities and forests is called for.

Acknowledgments We thank Breanne Grazier for her help in preparing the literature review for this paper. We also thank Lynnae Sutton for preparing the sample forest and community map. L. Buttolph, C. Dillingham, E. Grinspoon, W. Kay, M. Poe, C. Stuart, and L. Tobe collaborated with us in gathering and analyzing qualitative data on amenity migration from the case-study communities. Richard Haynes and two anonymous reviewers provided extremely helpful comments on an earlier version of the paper. We thank the Institute for Culture and Ecology and the USDA Forest Service for providing the funding to support our research and the preparation of this manuscript.

Open Access This article is distributed under the terms of the Creative Commons Attribution Noncommercial License which permits any noncommercial use, distribution, and reproduction in any medium, provided the original author(s) and source are credited.

\section{References}

Beckley, T. M. (1998). The Nestedness of Forest Dependence: A Conceptual Framework and Empirical Exploration. Society \& Natural Resources 11: 101-120.

Booth, D. E. (1999). Spatial Patterns in the Economic Development of the Mountain West. Growth and Change 30: 384-405.

Carroll, M. S. (1995). Community and the Northwestern Logger: Continuities and Change in the Era of the Spotted Owl. Westview, Boulder, CO.

Charnley, S. (tech. coord.) (2006a). Northwest Forest Plan: The First Ten Years (1994-2003). Socioeconomic Monitoring Results, 6 Volumes. Gen. Tech. Rep. PNW-GTR-649, US Department of Agriculture, Forest Service, Pacific Northwest Research Station, Portland, OR.

Charnley, S. (2006b). Northwest Forest Plan: The First Ten Years (1994-2003). Socioeconomic Monitoring Results, Vol. II: Timber and Nontimber Resources, Gen. Tech. Rep. PNW-GTR-649, US Department of Agriculture, Forest Service, Pacific Northwest Research Station, Portland, OR.

Charnley, S., and Donoghue, E. M. (2006). Northwest Forest Plan: The First Ten Years (1994-2003). Socioeconomic Monitoring Results. Vol. V: Public Values and Forest Management. Gen. Tech. Rep. PNW-GTR-649, US Department of Agriculture, Forest Service, Pacific Northwest Research Station, Portland, OR.

Cromartie, J. B., and Wardwell, J. M. (1999). Migrants Settling Far and Wide in the Rural West. Rural Development Perspectives 14: 2-8.

Daniels, S. E., Gobeli, C. L., and Findley, A. J. (2000). Reemployment Programs for Dislocated Timber Workers: Lessons from Oregon. Society and Natural Resources 13: 135-150.

Donoghue, E. M. (2003). Delimiting Communities in the Pacific Northwest, Gen. Tech. Rep. PNW-GTR-570, US Department of Agriculture, Forest Service, Pacific Northwest Research Station, Portland, OR.

Donoghue, E. M., and Sturtevant, V. E. (2007). Social Science Constructs in Ecosystem Assessments: Revisiting Community Capacity and Community Resiliency. Society and Natural Resources 20: 899-912.

Donoghue, E. M., and Sutton, N. L. (2006). Socioeconomic Conditions and Trends for Communities in the Northwest Forest Plan Region, 1990 to 2000. In Charnley, S. et al. (eds.), 
Northwest Forest Plan: The First Ten Years (1994-2003). Socioeconomic Monitoring Results. Vol. III: Rural Communities and Economies. Gen. Tech. Rep. PNW-GTR-649, US Department of Agriculture, Forest Service, Pacific Northwest Research Station, Portland, OR, pp. 7-35.

Duffy-Deno, K. T. (1998). The Effect of Federal Wilderness on County Growth in the Intermountain Western United States. Journal of Regional Science 38: 109-136.

English, D. B. K., Marcouiller, D. W., and Cordell, H. K. (2000). Tourism Dependence in Rural America: Estimates and Effects. Society and Natural Resources 13(3): 185-202.

Forest Service (2008). Climate Change, Water, and Kids. http://www. fs.fed.us/kidsclimatechange (accessed 03/04/08).

Frentz, I. C., Farmer, F. L., Guldin, J. M., and Smith, K. G. (2004). Public Lands and Population Growth. Society and Natural Resources 17: 57-68.

Gallo, K., Lanigan, S. H., Eldred, P., Gordon, S. N., and Moyer, C. (2005). Northwest Forest Plan: The First Ten Years (1994-2003). Preliminary Assessment of the Condition of Watersheds. Gen. Tech. Rep. PNW-GTR-647, US Department of Agriculture, Forest Service, Pacific Northwest Research Station, Portland, OR.

Garber-Yonts, B. E. (2004). The Economics of Amenities and Migration in the Pacific Northwest: Review of Selected Literature with Implications for National Forest Management. Gen. Tech. Rep. PNW-GTR-617, US Department of Agriculture, Forest Service, Pacific Northwest Research Station, Portland, OR.

Goodstein, E. (1999). The Trade-off Myth: Fact and Fiction about Jobs and the Environment. Island Press, Washington, DC.

Harris, C. C., McLaughlin, W., Brown, G., and Becker, D. (2000). Rural Communities in the Inland Northwest: An Assessment of Small Communities in the Interior and Upper Columbia River Basins. Gen. Tech. Rep. PNW-GTR-477, US Department of Agriculture, Forest Service, Pacific Northwest Research Station, Portland, OR.

Helvoigt, T. L., Adams, D. M., and Ayre, A. L. (2003). Employment Transitions in Oregon's Wood Products Sector During the 1990s. Journal of Forestry 101: 42-46.

Hirt, P. W. (1994). A Conspiracy of Optimism: Management of the National Forests since World War Two. University of Nebraska Press, Lincoln, Nebraska.

Holmes, F. P., and Hecox, W. E. (2004). Does Wilderness Impoverish Rural Regions? International Journal of Wilderness 10: 34-39.

Huff, M. H., Raphael, M. G., Miller, S. L., Nelson, S. K., and Baldwin, J. (2006). Northwest Forest Plan: The First Ten Years (1994-2003). Status and Trends of Populations and Nesting Habitat for the Marbeled Murrelet. Gen. Tech. Rep. PNW-GTR650, US Department of Agriculture, Forest Service, Pacific Northwest Research Station, Portland, OR.

Hunter, L. M., Boardman, J. D., and Saint Onge, J. M. (2005). The Association Between Natural Amenities, Rural Population Growth, and Long-Term Residents' Economic Well-Being. Rural Sociology 70: 452-469.

Jackson, J., Lee, R., and Sommers, P. (2003). Monitoring the Community Impacts of the Northwest Forest Plan: An Alternative to Social Indicators. Society and Natural Resources 17: 223-233.

Johnson, K. M., and Beale, C. L. (1999). The Continuing Population Rebound in Nonmetro America. Rural Development Perspectives 13: $2-10$.

Johnson, K. M., and Cromartie, J. B. (2006). The Rural Rebound and its Aftermath: Changing Demographic Dynamics and Regional Contrasts. In Kandel, W. A., and Brown, D. L. (eds.), Population Change and Rural Society. Springer, Dordrecht, The Netherlands, pp. $25-49$.
Johnson, J. D., and Rasker, R. (1995). The Role of Economic and Quality of Life Values in Rural Business Location. Journal of Rural Studies 11: 405-416.

Judson, D. H., Reynolds-Scanlon, S., and Popoff, C. L. (1999). Migrants to Oregon in the 1990's: Working Age, Near-Retirees, and Retirees Make Different Destination Choices. Rural Development Perspectives 14: 24-31.

Kerkvliet, J., Plantinga, A. J., Eichman, H., and Hunt, G. L. (2007). Are Biodiversity Protections a Boon or Bane for Local Economies? Evidence from the Northwest Forest Plan. Unpublished paper, Department of Agricultural and Resource Economics, Oregon State University, Corvallis, OR.

Kruger, L. E., Mazza, R., and Stiefel, M. (2008). Amenity Migration, Rural Communities, and Public Lands. In Donoghue, E. M., and Sturtevant, V. (eds.), Forest Community Connections. Resources for the Future, Washington, D.C., pp. 127-142.

Kusel, J., Kocher, S., London, J., Buttolph, L., and Schuster, E. (2000). Effects of Displacement and Outsourcing on Woods Workers and Their Families. Society \& Natural Resources 13: $115-134$.

Lewis, D. J., Hunt, G. L., and Plantinga, A. J. (2002). Public Conservation Land and Employment Growth in the Northern Forest Region. Land Economics 78: 245-259.

Lewis, D. J., Hunt, G. L., and Plantinga, A. J. (2003). Does Public Lands Policy Affect Local Wage Growth? Growth and Change 34: 64-86.

Lint, J. (tech. coord.) (2005). Northwest Forest Plan: The First Ten Years (1994-2003). Status and Trends of Northern Spotted Owl Populations and Habitat. Gen. Tech. Rep. PNW-GTR-648, US Department of Agriculture, Forest Service, Pacific Northwest Research Station, Portland, OR.

Lorah, P., and Southwick, R. (2003). Environmental Protection, Population Change, and Economic Development in the Rural Western United States. Population and Environment 24: 255 272.

McGranahan, D. A. (1999). Natural Amenities Drive Rural Population Change. Agricultural Economic Report No. 781, US Department of Agriculture, Economic Research Service, Washington, DC.

McKean, J. R., Johnson, D. M., Johnson, R. L., and Taylor, R. G. (2005). Can Superior Natural Amenities Create High-Quality Employment Opportunities? The Case of Nonconsumptive River Recreation in Central Idaho. Society \& Natural Resources 18: 749-758.

Moeur, M., Spies, T. A., Hemstrom, M., Martin, J. R., and Alegria, J. (2005). Northwest Forest Plan: The First Ten Years (1994-2003). Status and Trend of Late-Successional and Old-Growth Forest. Gen. Tech. Rep. PNW-GTR-646, US Department of Agriculture, Forest Service, Pacific Northwest Research Station, Portland, OR

Nelson, P. B. (1999). Quality of Life, Nontraditional Income, and Economic Growth: New Development Opportunities for the Rural West. Rural Development Perspectives 14: 32-37.

Niemi, E., Whitelaw, E., and Johnston, A. (1999). The Sky Did NOT Fall: The Pacific Northwest's Response to Logging Reductions. ECONorthwest Paper prepared for Earthlife Canada Foundation and Sierra Club of British Columbia.

Phillips, R. H. (2006). Jobs and Income Associated with Resource and Recreation Outputs. In Charnley, S. et al. (eds.), Northwest Forest Plan: The First Ten Years (1994-2003). Socioeconomic Monitoring Results. Vol. III: Rural Communities and Economies. Gen. Tech. Rep. PNW-GTR-649. US Department of Agriculture, Forest Service, Pacific Northwest Research Station, Portland, OR, pp. 37-51.

Power, T. M. (1996). Lost Landscapes and Failed Economies: The Search for a Value of Place. Island Press, Washington, DC. 
Power, T. M. (2006). Public Timber Supply, Market Adjustments, and Local Economies: Economic Assumptions of the Northwest Forest Plan. Conservation Biology 20: 341-350.

Rasker, R. (2006). An Exploration into the Economic Impact of Industrial Development Versus Conservation on Western Public Lands. Society and Natural Resources 19: 191-207.

Rasker, R., and Hackman, A. (1996). Economic Development and the Conservation of Large Carnivores. Conservation Biology 10: 991-1002.

Reeves, G. H., Williams, J. E., Burnett, K. M., and Gallo, K. (2006). The Aquatic Conservation Strategy of the Northwest Forest Plan. Conservation Biology 20: 319-329.

Rudzitis, G. (1999). Amenities Increasingly Draw People to the Rural West. Rural Development Perspectives 14: 9-13.

Rudzitis, G., and Johnson, R. (2000). The Impact of Wilderness and Other Wildlands on Local Economies and Regional Development Trends. USDA Forest Service Proceedings RMRS-P-15-Vol 2, pp. 14-26. US Department of Agriculture, Forest Service, Rocky Mountain Research Station, Ft. Collins, CO.

Shumway, J. M., and Davis, J. A. (1996). Nonmetropolitan Population Change in the Mountain West: 1970-1995. Rural Sociology 61: 513-529.

Shumway, J. M., and Otterstrom, S. M. (2001). Spatial Patterns of Migration and Income Change in the Mountain West: The Dominance of Service-Based, Amenity-Rich Counties. Professional Geographer 53: 492-502.

Spies, T. A., Hemstrom, M. A., Youngblood, A., and Hummel, S. (2006). Conserving Old-Growth Forest Diversity in DisturbanceProne Landscapes. Conservation Biology 20: 351-362.
Stuart, C. (2006). Agency Jobs, Unit Reorganizations, and Budgets. In Charnley, S., et al. (eds.), Northwest Forest Plan: The First Ten Years (1994-2003). Socioeconomic Monitoring Results. Vol. III: Rural Communities and Economies. Gen. Tech. Rep. PNW-GTR649, US Department of Agriculture, Forest Service, Pacific Northwest Research Station, Portland, OR, pp. 53-75.

Thomas, J. W. (2003). Application of the Northwest Forest Plan in National Forests in California. US Department of Agriculture, Forest Service, Pacific Southwest Region, Vallejo, CA.

Thomas, J. W., Franklin, J. F., Gordon, J., and Johnson, K. N. (2006). The Northwest Forest Plan: Origins, Components, Implementation Experience, and Suggestions for Change. Conservation Biology 20: 277-287.

USDA (U.S. Department of Agriculture, Forest Service), and USDI (US Department of Interior, Bureau of Land Management). (1994). Final Supplemental Environmental Impact Statement on Management of Habitat for Late-Successional and Old-Growth Forest Related Species Within the Range of the Northern Spotted Owl. Portland, OR.

Vias, A. C. (1999). Jobs Follow People in the Rural Rocky Mountain West. Rural Development Perspectives 14: 14-23.

Vias, A. C., and Carruthers, J. I. (2005). Regional Development and Land Use Change in the Rocky Mountain West, 1982-1997. Growth and Change 36: 244-272.

Wilkinson, K. (1991). The Community in Rural America. Greenwood, New York.

Wilson, L. J. (2003). Change in Timber-Dependent Communities: A Comparison of Communities with Mill Closures to those Without. Watershed Research and Training Center Publication, Hayfork, CA. 